\title{
MENINGKATKAN AKTIFITAS DAN HASIL BELAJAR SENI BUDAYA PESERTA DIDIK KELAS VII.10II.10 SEMESTER DUA TAHUN PELAJARAN 2016/2017 DI SMP NEGERI 4 MATARAM DENGAN PENERAPAN MODEL DISCOVERY LEARNING
}

\author{
Eko Suti Turus
}

Guru Kelas VII.10 SMP Negeri 4 Mataram

\begin{abstract}
Abstrak. Penelitian ini bertujuan untuk mengetahui efektifitas penerapan pendekatan Saintifik Strategi Discovery Learning dan Metode Diskusi dalam upaya meningkatkan motivasi dan hasil belajar Peserta didik Kelas VII.10 SMP Negeri 4 Mataram. Manfaat penelitian ini adalah mendorong peserta didik untuk mengembangkan ketrampilan belajar dalam kelompok (kognitif) dan bersosiolisasi dengan teman sebagai dalam proses pembelajaran di kelas senyatanya. Dan bagi guru meningkatkan pengembangan pendekatan dan model pembelajaran dengan penerapan saintifik dan strategi discovery learning dalam pembelajaran kerja kelompok (kooperatif) dengan metode diskusi. Penelitian ini dilaksanakan dua siklus, masing-masing siklus kegiatannya adalah; perencanaan, pelaksanaan, observasi dan refleksi. Hasil akhir tindakan pada siklus II menunjukkan bahwa hasil observasi guru sebesar 4,57, hasil observasi Peserta didik mencapai skor rata-rata $(4,51)$. Sedangkan dampak dari peningkatan motivasi belajar adalah meningkatnya perolehan hasil belajar siswa mencapai nilai rata-rata $(83,64)$, artinya indicator keberhasilan $(\geq 4,0)$ dan hasil belajar $(\geq 75,00)$ telah terlampaui. Karena indicator keberhasilan telah terbukti penelitian dinyatakan berhasil dan dihentikan pada siklus II.
\end{abstract}

Kata Kunci : Motivasi dan hasil Belajar, Pendekatan Saintifik Strategi Discovery Learning.

\section{PENDAHULUAN}

Proses pembelajaran di SMP Negeri 4 Mataram secara umum sudah mengarah pada pola pembelajaran peserta didik aktif. Strategi pembelajaran sudah mengarah kepada pembelajaran kontekstual. pada umumnya di kelas sudah secara berkesinambungan dan terencana melaksanakan pembelajaran kontekstual yang berbasis keilmuan. Dalam kenyataannya pola pembelajaran ini mampu merubah mindset guru dan mindset peserta didik dari pembelajaran pola guru sentris ke pola pembelajaran peserta didik aktif. Proses pembelajaran di SMP Negeri 4 Mataram diselenggarakan secara interaktif, menyenangkan, menantang, inspriratif, meaktifitas peserta didik untuk berpartisipasi aktif serta memberikan ruang yang cukup bagi prakarsa, kreativitas, dan kemandirian sesuai dengan bakat, minat, kemampuan, dan perkembangan fisik serta psikologis peserta didik.

Secara umum peserta didik kelas VII.10 adalah berprestasi, berdedikasi, dan berdaya saing bila dibandingkan dengan kelas-kelas lain. Kendatipun demikian dalam kenyataan sehari-hari pada saat proses pembelajaran berlangsung masih saja ditemukan : 1) peserta didik yang lemah, aktifitas belajar rendah, 2) masih ada juga yang dujumpai main HP secara diam-diam, 3) ada juga yang keluar masuk kelas sesekali minta ijin tetapi kadang-kadang asal nyelonong saja tanpa permisi, 4) pada saat guru menugaskan untuk belajar dalam kelompok, berdiskusi sesama teman dalam kelompok masih juga dijumpai peserta didik yang cuek, acuh tidak mau ikut urum rembuh dalam proses diskusi kelompok selama proses pembelajaran di kelas senyatanya.

Faktor penyebab terjadinya situasi kelas yang sangat kurang kondusif dalam proses pembelajaran tersebut adalah berasal dari guru itu sendiri maupun berasal dari peserta didik. Selama ini guru mengajar cenderung mendominasi dengan gaya ceramah yang berapi-api tanpa memperdulikan kondisi peserta didik. Guru kelas VII.10 sekaligus sebagai peneliti sebenarnya sudah menerapkan pendekatan saintifik sebagaimana yang tertera pada Permen 103 tahun 2014 tentang standar proses, tetapi masih belum optimal dan belum sesuai dengan harapan. Sementara penyebab dari peserta adalah rendahnya kompetensi yang dimiliki serta kurang gairah dalam 
mengikuti pelajaran. Apapun yang ditugaskan oleh guru, peserta didik nampak cuek dan kurang peduli akan akibat yang akan terjadi pada dirinya.

Banyak solusi yang bisa dilakukan oleh peneliti, tetapi yang dianggap mampu meningkatkan aktifitas dan hasil belajar peserta didik kelas VII.10 yaitu dengan mengoptimalkan pendekatan "saintifik" dengan menggunakan strategi discovery learning dengan metode diskusi kelompok. Pendekatan saintifik ini memiliki keunggulan bila di bandingkan dengan pendekatan yang lain karena proses pembelajaran terdiri atas lima pengalaman belajar pokok yaitu;

a) Mengamati,

b) Menanya,

c) Mengumpulkan informasi,

d) Mengasosiasi, dan

e) Mengkomunikasikan. Dalam pengembangan kegiatan pembelajar dengan pendekatan saintifik ini dirancang sebagai berikut;

1) kegiatan pembelajaran disusun untuk dapat melaksanakan proses pembelajaran secara professional, 2) kegiatan pembelajaran memuat rangkaian kegiatan manajerial yang dilakukan guru agar peserta didik dapat melakukan kegiatan seperti di silabus, 3) kegiatan pembelajaran untuk setiap pertemuan merupakan scenario/langkah-langkah guru agar peserta didik aktif belajar. Kegiatan ini diorganisasikan menjadi kegiatan: pendahuluan, inti dan penutup.

Untuk membuktikan bahwa pendekatan saintifik strategi discovery learning dengan metode diskusi dapat meningkatkan aktifitas dan hasil belajar peserta didik kelas VII.10 semester dua tahun pelajaran 2016/2017 maka dipandang perlu untuk mengadakan penelitian tindakan kelas (PTK) dengan judul "Meningkatkan Aktifitas Dan Hasil Belajar Seni Budaya Peserta Didik Kelas VII.10 Semester Dua Tahun Pelajaran 2016/2017 Di SMP Negeri 4 Mataram Dengan Penerapan Model Discovery Learning".

\section{Rumusan Masalah}

"Apakah dengan mengoptimalkan penerapan pendekatan Saintifik strategi
Discovery Learning dapat meningkatkan aktifitas dan hasil belajar peserta didik kelas VII.10 semester dua tahun pelajaran 2016/2017 di SMP Negeri 4 Mataram?”

\section{Tujuan Penelitian}

untuk mengetahui efektifitas penerapatan pendekatan Saintifik strategi Discovery Learning dalam upaya peningkatan aktifitas dan hasil belajar peserta didik kelas VII.10 semester dua tahun pelajaran 2016/2017 di SMP Negeri 4 Mataram.

\section{Manfaat Penelitian \\ * Bagi Peserta Didik}

1. Mendorong peserta didik untuk mengembangkan ketrampilan belajar dalam kelompok (kognitif) dan bersosiolisasi dengan teman sebagai dalam proses pembelajaran di kelas senyatanya.

2. Aktifitas belajar bagi peserta didik dalam upaya pemahaman secara mandiri (eksplorasi) terhadap mata pelajaran yang dipelajari sehingga hasil belajar dapat ditingkatkan.

\section{* Bagi Guru kelas VII.10}

1. Meningkatkan pengembangan pendekatan dan model pembelajaran dengan penerapan saintifik dan strategi discovery learning dalam pembelajaran kerja kelompok (kooperatif).

2. Menumbuhkan aspirasi secara ilmiah dalam menjalankan profesi keguruan terutama dalam pengembangan keprofesian berkelanjutan (PKB) bagi guru kelas VII.10.

\section{KAJIAN PUSTAKA}

Aktivitas belajar adalah aktivitas yang bersifat fisik maupun mental. Dalam proses belajar kedua aktivitas itu harus saling berkaitan. Lebih lanjut lagi piaget menerangkan dalam buku Sardiman bahwa jika seorang anak berfikir tanpa berbuat sesuatu, berarti anak itu tidak berfikir (Sardiman, 2011:100).

Nanang Hanafiah dan Cucu Suhana (2010:24) menjelaskan bahwa aktivitas belajar dapat memberikan nilai tambah (added value) bagi peserta didik, berupa halhal berikut ini:

1. Peserta didik memiliki kesadaran (awareness) untuk belajar sebagai wujud adanya aktifitas internal untuk belajar sejati. 
2. Peserta didik mencari pengalaman dan langsung mengalami sendiri, yang dapat memberikan dampak terhadap pembentukan pribadi yang integral.

3. Peserta didik belajar dengan menurut minat dan kemampuannya.

4. Menumbuh kembangkan sikap disiplin dan suasana belajar yang demokratis di kalangan peserta didik.

5. Pembelajaran dilaksanakan secara konkret sehingga dapat menumbuh kembangkan pemahaman dan berfikir kritis serta menghindarkan terjadinya verbalisme.

6. Menumbuh kembangkan sikap kooperatif dikalangan peserta didik sehingga sekolah menjadi hidup, sejalan dan serasi dengan kehidupan di masyarakat di sekitarnya.

Dalam penelitian ini yang dimaksud dengan aktifitas belajar adalah kegiatan peserta didik mengingat, memecahkan masalah, menganalisis faktor-faktor, melihat hubungan-hubungan, dan membuat keputusan terhadap masalah yang diberikan oleh guru mata pelajaran Seni Budaya kelas VII.10 di SMP Negeri 4 Mataram.

\section{Hasil belajar}

Mukhtar (2003:54) mengatakan bahwa pengertian hasil belajar tidak dapat dipisahkan dan apa yang terjadi dalam aktifitas pembelajaran baik di kelas maupun diluar kelas. Apa yang dialami oleh peserta didik dalam proses pengembangan kemampuannya merupakan apa yang diperoleh dalam belajar dan pengalaman tersebut pada akhirnya dipengaruhi oleh beberapa faktor diantaranya keadaan kognitif, afektif dan psikomotornya pada waktu belajar. Kualitas pengajaran yang diterimanya dan cara pengelolaan proses interaksi yang dilakukan oleh guru.

Masalah evaluasi hasil belajar meliputi alat ukur yang digunakan, cara menggunakan, cara penilaian dan evaluasinya (Harus Rasid dan Mansur, 2008:9). Evaluasi hasil belajar yang berhubungan dengan tugas guru rutin dilakukan evaluasi hasil, yang juga dijadikan umpan balik, evaluasi hasil bertujuan menilai apakah hasil belajar dicapai sesuai dengan tujuan (Lukmanul Hakim, 2008:165).
Pakar pendidikan lain mendefinisikan bahwa yang dimaksud hasil belajar adalah perubahan perilaku secara keseluruhan bukan salah satu aspek potensi kemanusiaan saja (Supriyono, 2009:19). Berbeda dengan pendapatnya Bloom (Dalam Sumiati danAska, 2008). Hasil belajar mencakup kemampuan kognitif, afektif, dan psikomotorik. Jadi pendapat ini mengisyaratkan bahwa haasil belajar peserta didik harus diukur dengan Hasil Karya/Lukisan, tes sikap, dan kemampuan skil secara nyata selama proses pembelajaran di kelas senyatanya.

Dalam penelitian ini yang dimaksud dengan hasil belajar adalah hasil karya berupa lukisan yang dilaksanakan pada akhir pembelajaran dan nilai hasil diskusi kelompok yang dinilai secara perorangan.

\section{Pendekatan}

Pendekatan dalam pembelajaran adalah peserta didik/peserta yang aktif. Titik tolak pemikiran bahwa peserta didik diajar dan guru mengajar beralih kepandangan bahwa peserta didik belajar, peserta didik mempelajari beberapa hal yang terus menerus dalam perjalanan hidupnya (Sumiati dan Aska, 2008:8). Dalam praktiknya pendekatan ini selalu disandingkan dengan pembelajaran yang konstektual. Dengan pembelajaran ini peserta didik akan memperoleh pengalaman belajar yang mengesankan dan akan diabadikan dalam kehidupan sebagai sosok yang demokratis, berfikir kreatif, yang selalu mengedapkan nilai-nilai kekeluargaan dan kegotongroyongan.

Pembelajaran dengan pendekatan saintifik adalah pembelajaran yang terdiri atas kegiatan mengamati (untuk mengidentifikasi hal-hal yang ingin diketahui), merumuskan pertanyaan (dan merumuskan hipotesis), mencoba/mengumpulkan data (informasi) dengan berbagai teknik, mengasosiasi/ menganalisis/mengolah data (informasi) dan menarik kesimpulan serta mengkomunikasikan hasil yang terdiri dari kesimpulan untuk memperoleh pengetahuan, keterampilan dan sikap. Kurikulum 2013 mengembangkan sikap spiritual, sikap sosial, pengetahuan, dan keterampilan peserta didik. (Permendikbud Nomor 54/2013) Bagaimana Kurikulum 2013 memfasilitasi peserta didik 
memperoleh nilai-nilai, pengetahuan, dan keterampilan secara berimbang?, bagaimana proses pembelajaran dilaksanakan?

Berikut contoh kegiatan belajar dan deskripsi langkah-langkah pendekatan saintifik pada pembelajaran kurikulum 2013 adalah:

1. Mengamati: membaca, mendengar, menyimak, melihat (tanpa atau dengan alat) untuk mengidentifikasi hal-hal yang ingin diketahui - Mengamati dengan indra (membaca, mendengar, menyimak, melihat, menonton, dan sebagainya) dengan atau tanpa alat.

2. Menanya: mengajukan pertanyaan tentang hal-hal yang tidak dipahami dari apa yang diamati atau pertanyaan untuk mendapatkan informasi tambahan tentang apa yang diamati - Membuat dan mengajukan pertanyaan, tanya jawab, berdiskusi tentang informasi yang belum dipahami, informasi tambahan yang ingin diketahui, atau sebagai klarifikasi.

3. Mencoba/mengumpulkan data (informasi): melakukan eksperimen, membaca sumber lain dan buku teks, mengamati objek/kejadian/aktivitas, wawancara dengan narasumber Mengeksplorasi, mencoba, berdiskusi, mendemonstrasikan, meniru bentuk/gerak, melakukan eksperimen, membaca sumber lain selain buku teks, mengumpulkan data dari nara sumber melalui angket, wawancara, dan memodifikasi/ menambahi/mengembangkan.

4. Mengasosiasikan/mengolah informasi: peserta didik mengolah informasi yang sudah dikumpulkan baik terbatas dari hasil

kegiatan mengumpulkan/eksperimen mau pun hasil dari kegiatan mengamati dan kegiatan mengumpulkan informasi mengolah informasi yang sudah dikumpulkan, menganalisis data dalam bentuk membuat kategori, mengasosiasi atau menghubungkan fenomena/informasi yang terkait dalam rangka menemukan suatu pola, dan menyimpulkan.

5. Mengkomunikasikan: peserta didik menyampaikan hasil pengamatan, kesimpulan berdasarkan hasil analisis secara lisan, tertulis, atau media lainnya menyajikan laporan dalam bentuk bagan, diagram, atau grafik; menyusun laporan tertulis; dan menyajikan laporan meliputi proses, hasil, dan kesimpulan secara lisan.

6. (Dapat dilanjutkan dengan) Mencipta: peserta didik menginovasi, mencipta, mendisain model, rancangan, produk (karya) berdasarkan pengetahuan yang dipelajari.

\section{Strategi Discovery Learning}

Strategi discovery learning adalah teori belajar yang didefinisikan sebagai proses pembelajaran yang terjadi bila pelajar tidak disajikan dengan pelajaran dalam bentuk finalnya, tetapi diharapkan mengorganisasi sendiri. Discovery terjadi bila individu terlibat, terutama dalam penggunaan proses mentalnya untuk menemukan beberapa konsep dan prinsip. Discovery dilakukan melalui observasi, klasifikasi, pengukuran, prediksi, penentuan dan inferi. Discovery learning merupakan pembentukan kategorikategori atau konsep-konsep, yang dapat memungkinkan terjadinya generalisasi.

Peserta didik dikatakan memahami suatu konsep apabila mengetahui lima unsur dari konsep itu, meliputi: 1) Nama; 2) Contoh-contoh baik yang positif maupun yang negatif; 3) Karakteristik, baik yang pokok maupun tidak; 4) Rentangan karakteristik; 5) Kaidah

\section{Kelebihan Penerapan Discovery Learning}

1. Membantu peserta didik untuk memperbaiki dan meningkatkan keterampilan-keterampilan dan prosesproses kognitif.

2. Pengetahuan yang diperoleh melalui metode ini sangat pribadi dan ampuh karena menguatkan pengertian, ingatan dan transfer.

3. Menimbulkan rasa senang pada peserta didik, karena tumbuhnya rasa menyelidiki dan berhasil.

4. Metode ini memungkinkan peserta didik berkembang dengan cepat dan sesuai dengan kecepatannya sendiri.

5. Peserta didik mengarahkan kegiatan belajarnya sendiri dengan melibatkan akal dan aktifitasnya. 
6. Strategi ini dapat membantu peserta didik memperkuat konsep dirinya, karena memperoleh kepercayaan bekerja sama dengan yang lainnya.

7. Berpusat pada peserta didik dan guru yang bersama berperan aktif mengeluarkan gagasan-gagasan.

8. Membantu peserta didik menghilangkan skeptisme (keragu-raguan) karena mengarah pada kebenaran yang final dan tertentu atau pasti.

9. Peserta didik akan mengerti konsep dasar dan ide-ide lebih baik;

10. Membantu dan mengembangkan ingatan dan transfer kepada situasi proses belajar yang baru;

11. Mendorong peserta didik berfikir dan bekerja atas inisiatif sendiri;

12. Mendorong peserta didik berfikir intuisi dan merumuskan hipotesis sendiri;

13. Memberikan keputusan yang bersifat intrinsik;

14. Situasi proses belajar menjadi lebih terangsang;

15. Proses belajar meliputi sesama aspeknya peserta didik menuju pada pembentukan manusia seutuhnya,

16. Meningkatkan tingkat penghargaan pada peserta didik.

17. Kemungkinan peserta didik belajar dengan memanfaatkan berbagai jenis sumber belajar.

18. Dapat mengembangkan bakat dan kecakapan individu.

\section{Kerangka Konseptual}

Kerangka konseptual ini menggambarkan hubungan antara variabel tindakan dan variabel harapan. Variabel tindakan yaitu mengoptimalkan penerapan pendekatan saintifik strategi discoveri learning dan metode diskusi, sedangkan variabel harapan adalah meningkatkan aktifitas dan hasil belajar.

\section{Hipotesis Tindakan}

Jika penerapan pendekatan saintifik strategi Discovery Learning dilaksanakan secara optimal maka aktifitas dan hasil belajar peserta didik kelas VII.10 semester dua tahun pelajaran 2016/2017 dapat ditingkatkan.

\section{PROSEDUR PENELITIAN \\ Setting Penelitian}

Penelitian tindakan kelas (PTK) ini akan dilaksanakan di kelas VII.10 SMP Negeri 4 Mataram semester dua tahun pelajaran 2016/2017, dengan jumlah peserta didik 33 orang.

\section{Faktor yang Diteliti}

1. Faktor Guru: yaitu dengan mengganti cara guru membuat Rencana Pelaksanaan Pembelajaran (RPP) dan pelaksanaannya dalam pembelajaran di kelas senyatanya dengan menerapkan pendekatan saintifik strategi Discovery Learning dalam upaya meningkatkan aktifitas dan hasil belajar peserta didik Kelas VII.10 SMP Negeri 4 Mataram.

2. Faktor Peserta Didik: yaitu peningkatan aktifitas dan hasil belajar yang terlihat pada perilaku peserta didik selama diskusi kelompok, yang berdampak pada peningkatan aktifitas dan hasil belajar peserta didik Kelas VII.10 Semester dua Tahun Pelajaran 2016/2017 di SMP Negeri 4 Mataram.

\section{Rencana Tindakan}

Tindakan nyata yang dilakukan oleh guru selaku peneliti adalah dengan menggunakan siklus. Gambaran siklus dalam penelitian ini adalah sebagai berikut:

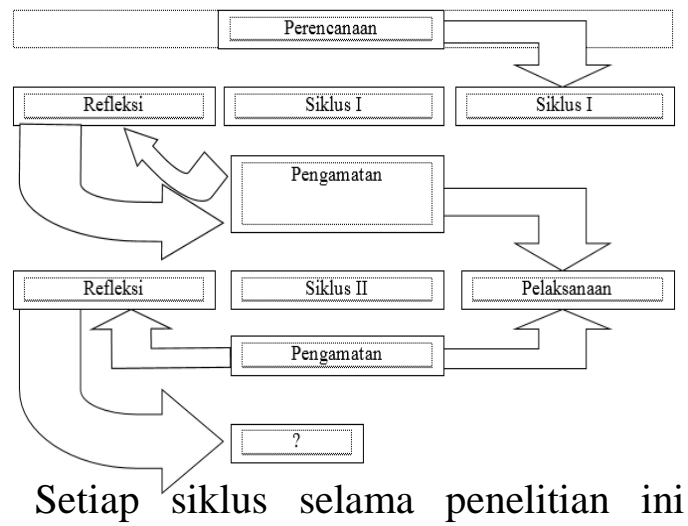
berisi 4 (empat) tahapan yaitu: 1) Perencanaan (Planning), 2) Pelaksanaan (Action), 3) Observasi (Observation), dan 4) Refleksi (Reflection).

\section{Siklus Tindakan}

Masing-masing tahapan dalam setiap siklus berisikan kegiatan-kegiatan nyata yang akan dilaksanakan. Untuk mendapatkan tentang rincian kegiatan pada setiap tahapa dapat dijelaskan sebagai berikut: 


\section{SIKLUS I}

1. Menyusun Rencana Pelaksanaan Pembelajaran (RPP) dengan skenario sesuai dengan aturan main model pembelajaran saintifik strategi Discovery Learning.

2. Menyiapkan sumber, bahan, dan semua alat yang digunakan dalam penelitian.

3. Menyusun/membuat lembar observasi guru dan lembar observasi peserta didik.

4. Menyusun alat evaluasi.

Tahap Pelaksanaan (Action)

1. Guru membagi peserta didik menjadi 6 (enam) kelompok kecil, masing-masing kelompok beranggotakan 5-6 orang peserta didik.

2. Masing-masing kelompok diberikan tugas/soal untuk dipecahkan bersama dalam kelompok, selanjutnya guru berkeliling untuk membimbing kelompok utamanya yang mengalami kesulitan/permasalahan.

3. Masing-masing kelompok maju kedepan untuk mempresentasikan hasil kerja kelompok secara bergiliran.

4. Hasil Karya/Lukisan

Tahap Observasi (Observation)

1. Observasi guru : Dilakukan oleh pengawas pembimbing dalam melaksanakan Penelitian Tindakan Kelas (PTK).

2. Observasi Peserta didik: Dilakukan oleh guru mata pelajaran Seni Budaya sebagai peneliti dalam Penelitian Tindakan Kelas (PTK) pada kegiatan diskusi kelompok dan presentasi kelompok.

Tahap Refleksi (Reflection)

1. Renungan hasil perolehan data

2. Pengolahan dan analisa data hasil penelitian

3. Mencocokkan hasil analisa data dengan indikator keberhasilan

4. Rencana perbaikan dan tindak lanjut

SIKLUS II

Pada siklus ini semua kegiatan dan tahapan selama penelitian adalah sama, sifatnya mengulang dan memperbaiki terhadap tindakan yang masih memerlukan penyempurnaan dan pembenaran sebagaimana mestinya.

Data dan Cara Pengambilannya.
Yang menjadi sumber data dalam penelitian tindakan kelas (PTK) ini adalah semua peserta didik kelas VII.10 semester dua tahun pelajaran 2016/2017 di SMP Negeri 4 Mataram dan peneliti.

Jenis Data

Adapun jenis data yang dikumpulkan dalam pelaksanaan penelitian tindakan kelas (PTK) ini meliputi :

- Jenis data yang berasal dari guru selaku peneliti

1). Data tentang Rencana Pelaksanaan Pembelajaran (RPP)

2). Data Pelaksanaan Pembelajaran

- Jenis data yang berasal dari peserta didik

1). Data kemajuan aktifitas belajar

2). Data hasil diskusi kelompok

3). Data hasil belajar

\section{Cara Pengambilan data}

- Data kegiatan pembelajaran diambil dari RPP yang dibuat oleh guru dan lembar observasi pelaksanaan model pembelajaran strategi Discovery Learning

- Data kemajuan aktifitas belajar; diambil dari lembar observasi selama diskusi kelompok.

- Data kemajuan hasil belajar; diambil dari laporan individu hasil diskusi kelompok dan hasil Hasil Karya/Lukisan yang dilaksanakan pada akhir proses pembelajaran

\section{Teknik analisa data}

Untuk menganalisis data akan dilakukan melalui analisis deskriptif kuantitatif melalui pendataan, analisis dan pembahasan terhadap data yang diperoleh dengan mencocokkan tingkat keoptimalan terhadap capaian indikator keberhasilan yang ada.

\section{Indikator Keberhasilan}

1. guru telah dinyatakan berhasil melaksanakan proses pembelajaran dengan pendekatan saintifik strategi Discovery Learning, bila telah mencapai skor rata-rata $\geq 4,00$ (kategori baik)

2. Aktifitas belajar peserta didik kelas VII.10 dinyatakan telah meningkat jika $85 \%$ dari jumlah peserta didik telah memperoleh skor rata-rata $\geq 4,0$ dan hasil belajar dinyatakan telah meningkat jika $85 \%$ dari jumlah peserta didik 
memperoleh nilai rata-rata $\geq 80,00$ (sesuai KKM).

\section{HASIL DAN PEMBAHASAN}

Pada tahapan ini yang telah dilakukan oleh guru selaku peneliti adalah; 1) menyusun RPP dengan skenario pembelajaran discovery learning, 2) telah berhasil menyiapkan alat, sumber, bahan yang diperlukan dalam penelitian, 3) berhasil menyusun instrument observasi guru dan instrument observasi peserta didik, dan 4) menyusun alat evaluasi.

\section{Tahap Pelaksanaan}

1. Guru menyampaikan materi pelajaran dengan pendekatan saintifik dengan kegiatan mengamati dan menanya

2. Peserta didik dibagi menjadi 6 kelompok kecil yang anggotanya 5-6 orang peserta didik secara heterogen

3. Peserta didik berdiskusi dengan strategi discovery learning dengan kegiatan pokoknya memecahkan persoalan/soalsoal yang menjadi tanggung jawabnya.

4. Selama peserta didik berdiskusi, guru berkeliling membimbing kelompok sekaligus melakukan observasi/pengamatan terhadap aspekaspek yang telah direncanakan.

5. Masing-masing kelompok secara bergiliran mempresentasikan di depan kelas yang diikuti oleh semua anggota kelompok.

6. Guru mengamati/mengobservasi ketrampilan peserta didik selama persentasi sesuai dengan aspek pengamatan ketrampilan yang telah di rencanakan.

7. Hasil Karya/Lukisan

\section{Tahap Observasi}

Observasi guru memperoleh skor ratarata sebesar 3,29, observasi peserta didik memperoleh skor rata-rata sebesar 3,24, dan Perolehan hasil belajar dalam bentuk Hasil Karya/Lukisan memperoleh nilai rata-rata sebesar 76,21.

\section{Tahap Refleksi}

1. Renungan data hasil perolehan data pada siklus I

2. Pengolahan data hasil observasi guru, peserta didik dan nilai tugas individual dan Hasil Karya/Lukisan.

3. Mencocokkan hasil yang ada dengan Indikator keberhasilan.
4. Merencanakan perbaikan terhadap jenis tindakan yang menyebabkan belum tuntas Indikator keberhasilan. Oleh karena Indikator keberhasilan belum terbukti maka penelitian dilanjutkan ke siklus II.

\section{SIKLUS I \\ Tahap Perencanaan}

Dalam tahapan ini ada beberapa kendala yang dihadapi diantaranya dalam menyusun RPP dengan skenario penerapan pendekatan Saintifik strategi Discovery Learning dan Metode Diskusi, menyiapkan alat, sumber, bahan yang diperlukan dalam proses pembelajaran. Sedikit kendala yang dihadapi yaitu dalam penyediaan LCD, dalam penyusunan instrument observasi guru maupun instrument observasi peserta didik. tetapi setelah beroksultasi kepada pembimbing, kendala yang dihadapi dapat diatasi dengan baik dan kegiatan dapat berjalan dengan lancar.

\section{Tahap Pelaksanaan}

a. Mengamati

- Guru menugaskan kepada peserta didik secara berkelompok untuk menggali informasi dari buku paket tentang materi pelajaran yang disajikan.

- Guru menjelaskan materi pelajaran dan memberikan contoh konkrit yang bisa dimengerti oleh peserta didik

b. Menanya

- Guru memberikan trik-trik kepada peserta didik tentang tata cara bertanya yang baik dan benar sesuai dengan materi pelajaran yang sedang disajikan.

- Peserta didik secara teratur bertanya tentang hal-hal yang belum dimengerti sesuai materi yang sedang dipelajari.

c. Mencoba (mengumpulkan data/informasi)

- Secara berkelompok peserta didik mendiskusikan masalah yang menjadi tanggung jawabnya.

- Melakukan eksperimen dalam kelompok terhaadap permasalahan yang sedang di diskusikan

- Mengumpulkan data yang berasal dari semua anggota kelompok

d. Mengasosiasikan/mengolah informasi

- Semua anggota kelompok menjawab dan menelaah semua jawaban yang telah di diskusikan bersama 
- Hasil jawaban di analisis bersama untuk bisa di paparkan di depan kelas pada saat menyampaikan informasi

- Kelompok membuat kesepakatan akhir dari hasil diskusi kelompok

e. Mengkomunikasikan

1. Guru kembali menyampaikan uraian materi pelajaran terkait dengan hasil kegiatan mengamati, menanya, mencoba, dan mengolah informasi.

2. Guru mempersilahkan kepada semua anggota kelompok untuk menginformaasikan hasil kerja kelompoknya.

3. Semua peserta didik secara berkelompok menanggapi setiap paparan dari kelompok lain

4. Peserta didik dengan bimbingan guru membuat kesimpulan bersama dari seluruh permasalahan/soal yang menjadi tanggung jawabnya.

5. Hasil Karya/Lukisan.

\section{Tahap Observasi}

Observasi guru memperoleh skor ratarata $(3,29)$, sementara Indikator keberhasilan yang diharapkan $(\geq 4,0)$, Hasil observasi peserta didik dalam upaya peningkatan aktifitas dan hasil belajar peserta didik kelas VII.10 semester dua tahun pelajaran 2016/2017 di SMP Negeri 4 Mataram diperoleh skor rata-rata $(3,24)$. Indikator keberhasilan ( $\geq$ 4,0). Dari hasil Hasil Karya/Lukisan yang materinya hanya sekitar yang diajarkan pada saat itu juga, diperoleh nilai rata-rata sebesar 76,21 kategori cukup.

\section{Tahap Refleksi}

Hasil analisa data peningkatan aktifitas belajar pada siklus I ini $(3,24)$ sedangkan yang diminta dalam Indikator keberhasilan $(\geq$ $4,0)$, ini artinya belum berhasil. Upaya nyata yang akan ditingkatkan dalam proses pembelajaran berikutnya yang termasuk tindakan pada siklus II adalah: 1) guru akan mengoptimalkan pendekatan strategi discovery learning dengan baik, 2) kekurangan/kesalahan yang terjadi di siklus I akan diminimalkan dengan cara menyusun skenario pembelajaran yang lebih efektif dan dapat diserap oleh semua peserta didik.

Karena Indikator keberhasilan belum tercapai, penelitian tindakan kelas (PTK) dilanjutkan ke siklus II dengan harapan optimalisasi penerapan strategi pembelajaran dengan pendekatan saintifik strategi Discovery Learning dapat meningkatkan aktifitas belajar peserta didik kelas VII.10 semester dua tahun pelajaran 2016/2017 di SMP Negeri 4 Mataram.

\section{DESKRIPSI SIKLUS II}

\section{Tahap Perencanaan}

Pada tahapan ini jenis kegiatan yang dilakukan masih mengacu pada kegiatan siklus I, bedanya hanya terjadi perbaikan seperlunya yaitu: 1) penyusunan RPP dengan mengacu pada pendekatan saintifik strategi discovery learning dan diskusi kelompok dan penyempurnaan pada bagian skenario pembelajaran, 2) menyiapkan alat, sumber, bahan yang diperlukan dalam proses tindakan dikelas senyatanyan, 3) menyiapkan lembar observasi guru dan lembar observasi peserta didik sebagaimana pada siklus I, 4) menyiapkan alat evaluasi sebagaimana yang telah dibuat pada siklus I.

\section{Tahap Pelaksanaan}

Secara umum tahapan pelaksanaan proses pembelajaran pada siklus II ini masih mengacu pada pelaksanaan proses pembelajaran sebelumnya. Pemecahan yang dilakukan pada proses pembelajaran ini adalah: 1) pelaksanaan proses diskusi kelompok kecil lebih dioptimalkan, 2) pelaksanaan pembimbingan kelompok sekaligus observasi peserta didik lebih di efektifkan. Utamanya pengamatan peserta didik yang aktif, yang kurang aktif, peserta didik yang tidak aktif, dengan harapan proses analisa data lebih signifikan, 3)laporan hasil kerja kelompok yang dibuat secara individu yang dipresentasikan dikelas difokuskan, dan 4) pelaksanaan Hasil Karya/Lukisan sebagai perwujudan dari peningkatan hasil belajar peserta didik lebih diperketat.

\section{Tahap Observasi}

Observasi guru memperoleh skor ratarata sebesar 4,57, observasi peserta didik memperoleh skor rata-rata sebesar 4,51, dan Perolehan hasil belajar dalam bentuk Hasil Karya/Lukisan memperoleh nilai rata-rata sebesar 83,64.

\section{Tahap Refleksi}

1. Renungan atas perolehan data hasil observasi guru, observasi peserta didik, dan hasil Hasil Karya/Lukisan sebagai 
wujud dari peningkatan aktifitas dan hasil belajar peserta didik di kelas senyatanya.

2. Pengolahan data hasil observasi guru, observasi peserta didik, presentasi peserta didik dan Hasil Karya/Lukisan

3. Mencocokkan perolehan data hasil tindakan dengan Indikator keberhasilan yang telah ditetapkan.

4. Guru memberikan hadiah/reward kepada semua peserta didik kelas VII.10 atas keberhasilannya dalam upaya meningkatkan aktifitas belajar yang berdampak terhadap perolehan hasil belajar sesuai dengan KKM yang telah ditetapkan.

SIKLUS II

\section{Tahap Perencanaan}

Peneliti menyusun Rencana Pelaksanaan Pembelajaran (RPP) dengan memperhatikan kesalahan-kesalahan pada siklus I. peneliti lebih memfokuskan tentang Rencana strategi jitu sehingga proses pembelajaran dengan pendekatan Saintifik strategi Discovery Learning dapat terelaisasi dengan baik, karenanya dalam penyusunan skenario benar-benar dirinci dari tiap aspek pada proses pembelajaran dengan Discovery Learning.

Sebelum proses pembelajaran dilaksanakan, peneliti menyiapkan semua alat, bahan, dan segala sesuatunya sehingga dalam pelaksanaan proses pembelajaran berjalan sesuai dengan skenario yang telah direncanakan. Agar proses pembelajaran dapat teratasi maka peneliti juga menyiapkan lembar observasi guru dan lembar observasi peserta didik sebagai tolak ukur ketercapaian peningkatan aktifitas dan hasil belajar peserta didik kelas VII.10 SMP Negeri 4 Mataram.

\section{Tahap Pelaksanaan}

Pada tahap pelaksanaan di siklus II ini pada dasarnya masih mengacu pada pelaksanaan siklus I, yaitu penerapan pendekatan Saintifik strategi Discovery Learning. Bedanya pada siklus ini lebih dioptimalkan.

\section{Tahap Observasi}

Pada siklus II ini hasil observasi guru memperoleh skor rata-rata $(4,57)$ sementara Indikator keberhasilan yang diharapkan $(\geq$ 4,0), Upaya meningkatkan aktifitas belajar
Seni Budaya, PPKn, dan IPS peserta didik kelas VII.10 semester dua tahun pelajaran 2016/2017 di SMP Negeri 4 Mataram pada tahap I diperoleh skor rata-rata 4,51 sementara Indikator keberhasilan yang telah diharapkan adalah $(\geq 4,0)$, ini artinya perolehan skor rata-rata telah melampaui dari Indikator keberhasilan. Dampak nyata dari meningkatnya aktifitas belajar adalah hasil belajar juga meningkat, dari data hasil perolehan nilai rata-rata Hasil Karya/Lukisan adalah $(83,64)$ sementara pada siklus sebelumnya hanya $(76,21)$ berarti mengalami peningkatan yang sangat signifikan.

\section{Tahap Refleksi}

Hasil analisa data peningkatan aktifitas dan hasil belajar peserta didik pada siklus II adalah $(4,51)$ dan $(83,64)$ sedangkan Indikator keberhasilan $(\geq 4,0)$ dan $\geq 80,00$. Ini artinya pada siklus II hasilnya telah melampaui Indikator keberhasilan yang telah di tetapkan. Karena Indikator keberhasilan telah terbukti, maka tidak perlu ada upaya perbaikan dan penyempurnaan. Pendekatan Saintifik strategi Discovery Learning telah mampu meningkatkan aktifitas dan hasil belajar peserta didik yang ditandai dengan tercapainya Indikator keberhasilan dan terjadinya peningkatan hasil belajar peserta didik. "Penelitian Tindakan Kelas (PTK) dihentikan pada siklus II dengan hasil memuaskan."

\section{SIMPULAN DAN SARAN}

\section{Simpulan}

Penerapan pendekatan Saintifik Strategi Discovery Learning sangat efektif upaya untuk meningkatkan aktifitas dan hasil belajar peserta didik kelas VII.10 semester dua tahun pelajaran 2016/2017 di SMP Negeri 4 Mataram. Fakta telah menunjukkan perolehan rata-rata skor aktifitas belajar peserta didik pada siklus I ke siklus II sudah melampaui Indikator keberhasilan yang ditetapkan. Penelitian dinyatakan "berhasil" dan dihentikan pada siklus II.

\begin{tabular}{|c|l|c|c|c|c|}
\hline No $_{0}$ & \multicolumn{1}{|c|}{ Jenis Kegiatan } & $\begin{array}{c}\text { Indikator } \\
\text { keberhasilan }\end{array}$ & Siklus I & Siklus II & Keterangan \\
\hline 1. & Observasi Guru & $\geq 4,00$ & 3,29 & 4,57 & Meningkat \\
\hline 2. & Observasi Peserta didik & $\geq 4,00$ & 3,24 & 4,51 & Meningkat \\
\hline 5. & Hasil KaryaLLukisan & $\geq 80,00$ & 76,21 & 83,64 & Meningkat \\
\hline
\end{tabular}




\section{Saran-Saran}

Disarankan kepada guru sejawat untuk melaksanakan Penelitian Tindakan Kelas (PTK) dalam upaya untuk meningkatkan aktifitas dan hasil belajar peserta didik sesuai dengan mata pelajaran masing-masing.

Disarankan kepada para semua peserta didik kelas VII.10 SMP Negeri 4 Mataram untuk membiasakan belajar dengan pendekatan yang kontekstual utamanya strategi yang mampu membangkitkan aktifitas belajar peserta didik yang dampaknya hasil belajar dapat ditingkatkan seperti yang diharapkan.

\section{DAFTAR PUSTAKA}

Anonim, 2017, dalam http://dadangjsn.blogspot.com/2016/0 6/pengertiandefinisi-pendekatansaintifik.html, diambil tanggal 2 Februari 2017, Pukul 10.40 Wita

Arikunto, s. 2009, Penelitian Tindakan Kelas, Jakarta : Bumi Aksara.

Harun Rasyid dan Mansur, 2008, Penilaian Hasil Belajar, Bandung : CV Wacana Prima.

Lukmanul A, 2008, Perencanaan Pembelajaran, Bandung : CV Wacana Prima.

Mukhtar, 2003, Prosedur Penilaian, Jakarta : Rineka Cipta.

Nurhadi, 2003, Yasin ,B dan Sendule.A, 2003, Kontekstual dan Penerapannya dalam KBK, Malang : Unitipetas Negeri Malang.

Robert E Slavin, 2010, Cooperative Learning Teori, riset dan Praktik, Bandung : Nusa Media.

Sardiman, 2007, Indikator Dan Aktifitas Belajar Mengajar, Jakarta : Raja Grafindo Perkasa.

Supriono, 2009, Cooperative Learning Teori dan Aplikasi PAIKEM, Yogyakarta : Pustaka Pelajar.

Permen 81A Tahun 2013 Tentang Implementasi Kurikulum 2013

Permen 103 Tahun 2014 Tentang Standar Proses 